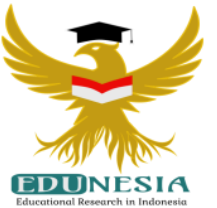

\title{
Correlation of Family Disharmony with Student Achievement in Islamic Education Lessons at SMP NUHA Banjarharjo Brebes
}

\author{
Muhammad Muslih \\ Islamic Religious Education, Akademi Maritim Cirebon, Indonesia \\ Corresponding Email: muslihmunaya@gmail.com, Phone Number: 0823 xxxx xxxx
}

\author{
Article History: \\ Received: May 04, 2021 \\ Revised: Jun 09, 2021 \\ Accepted: Jun 13, 2021 \\ Online First: Jun 23, 2021
}

\section{Keywords:}

Family Disharmony, Islamic

Education, Student

Achievement.

Kata Kunci:

Ketidakharmonisan keluarga, Pendidikan Agama Islam,

Prestasi belajar.

\section{How to cite:}

Muslih, M. (2021). Correlation of Family Disharmony with Student Achievement in Islamic Education Lessons at SMP NUHA Banjarharjo Brebes. Edunesia: Jurnal Ilmiah Pendidikan, 2 (3): 581-590.

This is an open access article under the $C C$-BY-NC-ND license

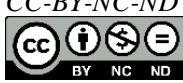

\begin{abstract}
Family harmony is one of the important factors in helping student achievement, because many students are raised in less harmonious families. The education and economy of their parents are relatively low, and they are also busy with making a living, all of which causes children's learning achievement to decline, especially in Islamic Religious Education lessons. This study aims to obtain data on the level of family disharmony of students at SMP NUHA Banjarharjo Brebes, in order to determine student achievement in Islamic Religious Education subjects and determine the relationship between family disharmony and student learning outcomes in Islamic Religious Education lessons at SMP NUHA Banjarharjo Brebes. The method used by the researcher is field research to collect data by observation, documentation, interviews, and questionnaires. Information that is qualitative is replaced with quantitative information with the technique of giving a value to all alternative answers. The results showed that the level of family disharmony of the students of SMP NUHA Banjarharjo Brebes was at a moderate level, the conclusion from the average value of student participants in Islamic religious learning was classified as moderate, and the correlation between students' family disharmony and student learning outcomes in Islamic Religious Education was classified as strong 0.77.
\end{abstract}

Abstrak: keharmonisan keluarga merupakan salah satu faktor penting dalam membantu prestasi belajar siswa, karena banyak siswa yang dibesarkan dalam keluarga yang kurang harmonis. Pendidikan dan ekonomi orang tua mereka yang relatif rendah, juga disibukkan dengan urusan mencari nafkah, semua itu menyebabkan prestasi belajar anak menurun, terutama dalam pelajaran Pendidikan Agama Islam. Penelitian ini bertujuan untuk memperoleh data dengan tingkat ketidakharmonisan keluaraga siswa SMP NUHA Banjarharjo Brebes, supaya mengetahui prestasi belajar siswa pada mata pelajaran Pendidikan Agama Islam dan mengetahui keterkaitan ketidakharmonisan keluarga dengan hasil belajar siswa pada pelajaran Pendidikan Agama Islam di SMP NUHA Banjarharjo Brebes. Metode yang digunakan peneliti adalah penelitian lapangan untuk mengumpulkan data dengan observsi, dokumentasi, wawancara, dan angket. Informasi yang bersifat kualitatif diganti jadi informasi kuantitatif dengan teknik beri nilai pada semua alternatif jawaban. Hasil penelitian menunjukan bahwa tingkat ketidakharmonisan keluarga siswa SMP NUHA Banjarharjo Brebes berada pada tingkat sedang, kesimpulan dari nilai rata- rata partisipan peserta didik pada pembelajaran Agama Islam adalah tergolong sedang, dan korelasi ketidakharmonisan keluarga peserta didik dan hasil belajar siswa pada pelajaran Pendidikan Agama Islam tergolong kuat 0,77 . 


\section{A. Introduction}

Education is very important especially for life because it cannot be divided from activities, both from individual activities, families and in society and the State. Education is essentially a reciprocal relationship between teachers and students. Interaction is an influential state between teachers and students (Sukmadinata, 2005).

According to Triwiyanto (2014) education is an effort to attract something in humans as an effort to provide programmed learning experiences in the form of formal, non-formal, and informal education at school and outside school, which lasts a lifetime aimed at optimizing individual abilities so that in the future they can play the role of life appropriately. Etymologically family in Javanese terms consists of two words, namely kawula and citizens. Kawula means servants and citizens are members (Aziz, 2015).

The word pair of family is happy, the equivalent is to be a happy family. That is, the goal of everyone who builds a household is to seek happiness in life. If someone is not successful in his career outside the home, but succeeds in building a strong and prosperous family, then he is still seen as a successful and happy person. On the other hand, a person who is successful outside the home, but his family is in disarray, then he is not called a lucky person, failure in his household will be reflected on his face, also reflected in his unhappy life pattern (Mubarak, 2016).

Family is usually what we call the first environment in education. In the family, a child functions as a learner, and parents have a role as educators, the child has the first contact with the family, and most importantly with parents (Desmita, 2009). With development, students interact within the scope which is very broad, namely within the school environment.

Peace and togetherness in the family will be created well if the family makes the teachings of Islam as the basis. On this basis, a sakinah family will be built. The love between parents, namely husband and wife, is a very basic reason for the realization of a sakinah family, family harmony is a very important factor in helping student learning outcomes. Learning is a process that involves various elements and conditions. Not a few students have high intelligence but have problems experiencing learning achievement problems because there are no factors that support and help student learning activities, so learning achievement decreases. One of the factors that support and assist student learning activities is family harmony.

The bond between family harmony and student learning outcomes of SMP NUHA Banjarharjo Brebes in the author's observation has conformity with the concept above. Many students of SMP NUHA Banjarharjo Brebes who at first seemed to have high intelligence as evidenced by good report cards at the previous education level, but then their achievements declined, as evidenced by daily test scores, mid-semester test scores, end-semester test scores, and result scores. study in one semester or their report cards. Based on preliminary research, the authors found that many students of SMP NUHA Banjarharjo Brebes were raised in families with relatively low levels of parental education, low economic levels as well, not close relationships, both parental relationships between other family members. The parents are busy with the business of making a living, even to go abroad. They try their best to meet the needs of the family. They have more time to work, causing less attention to their children's learning development.

However, not all children in the care of a less harmonious family get poor performance. The truth of these assumptions according to the author needs to be tested in research. Therefore, the researcher conducted a research on the bond of family disharmony 
with student achievement in the subject of Islamic Religious Education where the researcher had seen previous studies, namely Azizah in his research entitled family harmony ties with the learning outcomes of tenth grade students of SMK N 1 Salatiga. in 2017, there is a difference in the study where the author will examine junior high school students while the research that has been carried out by Azizah is at the high school level. The purpose of this research is to determine the level of family disharmony of junior high school students, in addition to knowing student learning outcomes in Islamic Religious Education subjects at SMP NUHA Banjarharjo Brebes, and furthermore to determine the bond of family disharmony with student learning achievement in Islamic Religious Education subjects at SMP NUHA Banjarharjo Brebes.

\section{B. Method}

The author uses a qualitative research approach. All data results will be collected one of them through interviews, observation, and documentation. After everything is obtained, the information obtained from the field will then be compiled by selecting and simplifying the data. After the stages are completed, then the data is submitted so that conclusions can be drawn.

The author distributes a questionnaire of 40 students who were sampled to find out the disharmony of the family of SMP NUHA Banjarharjo Brebes, this study refers to indicators of harmony (Mustofa, 2006), namely: (1) good relationships in the family, (2) the creation of love, (3) the existence of mutual understanding by all family members, (4) have a stable life of diversity, (5) There is support for children's learning activities, (6) Good family economic conditions, and (7) there is recreation in the family. Because disharmony is the opposite of harmony, the indicator of disharmony is:

1. Bad relationship in the family

2. There is no love

3. There is no mutual understanding of all family members

4. Not having a steady life of diversity

5. There is no support for children's learning activities

6. The family's economic situation is not good

7. No recreation in the family.

\section{Result and Discussion}

Questionnaire data distributed to 40 students in general can be conveyed that the level of family disharmony of SMP NUHA students in Banjarharjo Brebes is almost half $(40 \%)$ in the high category, a small portion $(22.5 \%)$ in the medium category, a small portion $(17.5 \%)$ in the low category, and a small portion $(20 \%)$ in the very low category.

To answer the second problem, in order to know the learning outcomes of students in Islamic Religious Education subjects, data in the form of daily test scores, mid-semester, and end-semester examinations in general can be conveyed that there are no students at all (0\%) SMP NUHA Banjarharjo Brebes which has high learning outcomes in Islamic Religious Education subjects. Most (65\%) students of SMP NUHA Banjarharjo Brebes have moderate learning outcomes in Islamic Religious Education. A small proportion (35\%) of students have low learning achievement in Islamic Religious Education. And none at all $(0 \%)$ of students whose learning outcomes in Islamic Religious Education subjects are very low. 
The correlation between students' family disharmony and student learning outcomes in Islamic religious education subjects at SMP NUHA Banjarharjo Brebes is 0.77. By referring to the guidelines for interpreting the correlation level (Anas Sudijono, 2009). The correlation between the relationship between family disharmony and learning achievement in Islamic Religious Education is strong. This means that other factors that affect student achievement at SMP NUHA Banjarharjo Brebes on Islamic Religious Education subjects other than family disharmony are only $23 \%$.

Family harmony has an important role in a person's growth and development. A child or teenager who is raised in a family social environment that is not good or family disharmony, then the risk of a child experiencing a personality disorder to become antisocial and deviant is greater than a child who is raised in a healthy or harmonious family (Marmin, 2013). Parenting patterns and conditions from the family have a significant influence on the development of a teenager (Rahmaningsih \& Martani, 2014).

\section{Family Harmony}

The family is the smallest social unit in society that is united by legal ties of marriage. Family harmony is a peaceful family, happy, organized, obedient, respectful, forgiving, helping each other in goodness, having a good work spirit, neighbors with mutual respect, obedient in worship, obedient to both parents, love of knowledge and use of knowledge. free time with good things and can fulfill the basics of the family (Basri, 2004). Included in the family are mothers and fathers and their children in the house and everything in it. The sakinah family plays a role in the realization of a harmonious society. However, the creation of a harmonious society is not only fully determined by good families, but the cultural system, values adopted by the local community also contribute to determining it (Ariwibowo, 2015).

From the above understanding, it can be concluded that a harmonious family is a happy family consisting of husband, wife and children, each of whom carries out their duties and obligations so as to create a harmonious, comfortable and peaceful atmosphere. Parameters of harmony in the family, are:

a. Elements of the family are not at odds, including those outside the family or society, we usually call it harmonious.

b. Family elements help each other, have enough time for family and community.

c. The family element obeys the regulations agreed by the family and community elements.

d. Family elements forgive each other, please help outside family members in terms of kindness, not expecting anything in return or in return.

e. The family element is strong in worship, and respects both parents.

f. Uses free time and likes science.

g. Love the attention of fellow family members and complement each other

Harmony, namely there is inequality, harmony, mutual understanding of each other and the existence of order. The initial harmony of the word "harmonious" means one direction, compatibility in the household (Singgih, 2008).

Family harmony must be formed from the start, when a human couple is about to climb the ladder of marriage, because family harmony does not just happen, but through a long process, this process begins when two people start choosing a partner. Every Muslim woman should choose a husband who is noble and obedient in carrying out religious teachings, so that he can carry out his obligations perfectly in raising a family, fulfilling his 
wife's rights, educating children, maintaining family honor and being responsible for meeting household needs. Men also have to choose women to be their life partners. He must pay attention to the criteria prescribed by Islam, including:

a. Choose on the basis of religion. What is meant by religion is understanding everything that is true about Islam and its use in everyday life.

b. Choosing on the basis of heredity. In this case, what is considered is the origin of the woman who will be chosen, whether from good descent or not.

c. Open close family. Not close family means that in choosing a mate it is advisable to avoid blood ties, because children born to blood partners are feared to be physically and mentally weak.

d. Prioritizing virgins or girls. In choosing a mate, it must be considered whether he is still a virgin / girl or not, because marrying a virgin / girl has fewer negative consequences than marrying a widow.

e. Prioritize fertile women. In this case, fertile women can be seen from the origin of their offspring, or can be seen from their health (Al-Barik, 2002).

From the above criteria, it is hoped that the couple can build a harmonious family, a harmonious family usually has the following characteristics:

a. Have a solid diversity life. The steady life of diversity in the family is reflected by the faith of family members, the family in Allah. All family members try to practice the teachings of Islam as best they can. For example, in the family it is customary to pray in congregation

b. Good relationship in the family. What is meant is that between family members there is a good relationship between the child and his parents and all other family members.

c. There is support for children's learning activities. In a harmonious family, both parents have an obligation to provide motivation for formal education for each family member, instill a sense of love for reading and invite children to continue their schooling so as not to stop in the middle of the road.

d. There is mutual understanding by all family members. All family members must understand the meaning between children and parents must always pay attention to children's education. Children must always know their duties and responsibilities as children. Likewise, parents must support their children in terms of learning and education.

e. Good conditions in the family economy. Both parents have sufficient income to be able to meet all basic needs and spend their money not exceeding what they earn.

f. The realization of mutual love. The harmony of both parents love, cherish, respect, trust, and deliberation if there are problems, they must forgive each other. Relationships with children must also be like that, lest there are differences that cannot be resolved. both parents can show affection, attention, be fair, not one-sided and open to each other, thus the child will express his problem without feeling forced.

g. There is recreation in the family. That once in a while the family is together for recreation, it refreshes the mind, in this case it does not have to go out of town for recreation, maybe occasionally go cycling with the whole family (Mustofa, 2001).

From the explanation above, the writer concludes that the characteristics of a harmonious family are (1) having a stable life of diversity, (2) good relationships in the family, (3) support for children's learning activities, (4) mutual understanding by all members. family, (5) good economic conditions (6) creation of affection, and (7) family recreation. 


\section{Factors that can affect Family Harmony are}

a. Faith Factor

Religious and moral factors are very important in choosing a mate. Because someone who has a high level of faith, will do everything with full awareness and sincerity to hope for the pleasure of Allah. If husband and wife have a high level of faith, it will be easier for them to create a sakinah family. Forming a sakinah family is a goal that must be achieved by the family. Families based on Islam will carry out their obligations perfectly in guiding the family. Each husband and wife will behave on the basis of the teachings of Islam, if they face problems, everything will be returned to Allah and His Messenger, Allah SWT says in QS An-Nisa, 4:59 which means:

"Then if you disagree about something, then return it to Allah (the Qur'an) and His Messenger (Hadith) if you truly believe in Allah and the Last Day. That is more important (for you) and better as a result" (Shiddiqi, 2008).

\section{b. Economic Factor}

Economic factors here include employment and a steady income. Both are important in fostering a family, because it will fulfill basic needs such as clothing, food, shelter, education, and health. (Bukhari, 1989)

In contrast to families whose head of family does not have a permanent job, the income will also be not fixed, so the family economy does not run smoothly. Families like this will focus on efforts to make ends meet, while other things are not paid attention to. It can almost be concluded that families with sufficient economics tend to find it easier to build a harmonious family, although this can be influenced by other factors.

\section{c. Environmental factor}

The environmental factor in question is the state of the environment where the family lives. (Zuhairini, 1992) A positive influence if the environment in which you live is in a good and religious environment so that it will encourage each family to carry out its functions and roles. The negative effect is if the environment where the family lives is in a bad environment.

From the explanation above, the writer summarizes which harmony in the family will be influenced by factors (1) religious or faith factors (2) Economic factors, (3) environmental factors

\section{Urgency in Family Harmony}

Family harmony has a very important role in the lives of husbands and wives, as well as for their children and for the Muslim community.

a. The urgency of family harmony for husband and wife life

A harmonious family will have a positive impact on the continuity of the husband and wife relationship. The husband will feel safe and peaceful at home, so that all tiredness and fatigue due to work will be quickly cured when he gets home. And the wife will feel peaceful, safe and at ease. The wife will carry out all her duties and obligations with joy. 
b. The urgency of family harmony for children

The first identifier introduced by parents is usually in the family. The family is also the first place of education, students first get education and get guidance from their parents and other family members. In the family, children also get the basics of personality at an early age, because at this age children are usually more sensitive to the influence of their education.

To be able to educate and deliver children to be pious children, family harmony is very important. Children will see and absorb knowledge from the people around them. A harmonious family will pay attention to the education, behavior and moral development of children.

In a harmonious family, children will get used to good speech, behave well and do everything with sincerity. Children will feel happy and at ease at home. So the expression my home is my heaven is very suitable to reflect a harmonious family.

c. For the surrounding community

Harmonious families have an important role in building society. A harmonious family will produce noble individuals, and behave Islamically. If each of the above families will form a religious society, which upholds morals and character, so that in society a harmonious relationship pattern will be formed.

From the explanation above, the author concludes that family harmony is very important, especially for the lives of husband and wife, for their children, and for the surrounding community. For the life of husband and wife, family harmony will give birth to a sakinah, mawaddah, warohmah family. For children, family harmony will be a good place for education for them. In a harmonious family they are prepared to live a good life in the future. For the surrounding community, a harmonious family has an important role in building society. A harmonious family will produce noble individuals, and behave Islamically.

\section{Family Disharmony}

The family is a social community formed from the relationship between husband and wife and children. However, the circumstances of a family will not always be harmonious. Every family life will not be free from various problems. In married life problems are always present, both big and small, which can cause disharmony. The form of disharmony in the family can have a negative influence on the individuals in it Several things can cause family disharmony.

a. Disharmony of feelings

1. Parents can't give love to their children.

2. Parents devote too much love to their children, so they become lazy, arrogant and selfish.

3. There is discrimination in the family. Individuals in the family often make distinctions.

b. Relationship disharmony

Sometimes, disharmony will arise in how both parents get along with their children. For example, children see directly their parents fighting, and committing acts of violence, or also directly seeing the disharmony of their parents. 
c. Disharmony in the rules

Family disharmony in the family occurs because there is no discipline. For example, giving children the freedom to do without any rules.

d. Disharmony due to supervisory issues

Due to the busyness of parents, supervision of children is often not carried out. Lack of supervision may also arise from unstable family relationships. Parents do not have clear rules, directions, and programs in educating their children, so the affairs of educating them are left to helpers.

e. Disharmony due to economic problems

Poverty can drive children out of school. Economic difficulties cause parents, whether father, mother or both father and mother to earn a living outside the area or abroad, they are willing to ignore their obligation to educate their children. The disharmony is also caused not only because of money shortages but also because of excess money. Usually in rich families, children are always in a life of luxury and love to spend time.

f. Disharmony due to social environment

The environment occupied by a family greatly influences the morals and personality of the community.

g. Disharmony due to bad actions of parents

Parents are role models for their children. So children usually follow behavior similar to their parents. Parents who commit acts of violence, whether husband against wife, or wife against husband, or against their children will result in bad conditions. This will affect the psychological condition of the family.

h. Disharmony due to divorce or death

Losing one of them would result in a cripple. Disharmony due to divorce will have an impact, both on the husband and wife themselves, and on their children.

From the explanation above, the writer concludes that there are at least seven things that can cause family disharmony, namely (1) disharmony of feelings, (2) disharmony in relationships, (3) disharmony in regulations, (4) disharmony due to supervisory problems, (5) disharmony due to economic problems, (6) disharmony due to the social environment, (7) disharmony due to bad actions of parents and due to divorce or death.

\section{The Relationship Between Family Disharmony and Learning Achievement}

1. The first and most important place of learning is the family. So a strong family based on religious values will be a liaison for children to have Islamic behavior and show their learning. Every child has an empty soul, not yet patterned. At some point, these traits will be given content, style and purpose, when the child has been in touch with many factors in the family and society. These traits are traits that are obtained based on experience in the household environment and will be seen in their form in the community.

2. Children who still do not understand anything, will be formed by the father and mother in the family environment. Children's talents and interests will grow well in a harmonious family environment. Family disharmony has a good correlation with learning outcomes. 


\section{Conclusion}

The family disorganization of SMP NUHA students in Banjarharjo Brebes is of moderate type. This type contains signs of poor communication within the family, the absence of mutual love for each family element, no mutual understanding among family elements, the absence of a steady religious life in the family, the absence of encouragement to teaching activities while children who have a poor family economy less established, and the absence of a picnic in the family.

From the results of the analysis for student learning outcomes, overall it can be concluded that the learning outcomes of students of SMP NUHA Banjarharjo towards Islamic Religious Education subjects are moderate. There are not even students who have high learning outcomes, and there are also no students who have the lowest learning outcomes.

The relationship between students' family disharmony and student achievement in Islamic Religious Education subjects at SMP NUHA Banjarharjo is 0.77. By referring to the guidelines for interpreting the correlation level, this figure shows that the correlation between the disharmony of the students' families and the learning outcomes of students in Islamic Religious Education lessons is high or strong.

\section{References}

Al-Barik, \& H. binti M. (2002). Ensiklopedia Wanita Muslimah (pp. 103-105). Darul Falah.

Ariwibowo. (2015). Perkawinan dan Keluarga (Keluarga Sakinah Ditengah Maraknya Perceraian.

(p. 15). Badan Penasihatan, Pembinaan dan Pelestarian Perkawinan ( BP4).

Aziz, S. (2015). Pendidikan Keluarga: Konsep dan Strategi (p. Hal. 15). Gava Media.

Basri, H. (2004). Merawat Cinta Kasih (p. 111). Pustaka Belajar Offset.

Bukhari. (1989). Agama Sumber Nilai-Nilai Pembinaan Anak (p. 13). Ramadhani.

Desmita. (2009). Psikologi Perkembangan (p. 19). Remaja Rosdakarya.

Fathurohman \& Sulistyorini. (2012). Belajar dan Pembelajaran (p. 213). Teras.

Hamalik, O. (1991). Metodologi Belajar dan Kesulitan-Kesulitan Belajar (p. 38). Tarsito.

Marmin. (2013). Kenakalan remaja sebagai permasalahan sosial dan upaya pengatasannya. Jurnal Ilmu-Ilmu Sosial Dan Humaniora, 1, 1-9.

Mubarak, A. (2016). Psikologi Keluarga (p. hal. 114). Madani.

Mujib, A. (2002). Nuansa-nuansa Psikologi Islam (p. 12). Raja Grafindo Persada.

Mustofa, A. (2001). Ensiklopedia Wanita Muslimah (pp. 12-14). Mitra Pustaka.

Mustofa, A. (2006). Untaian Mutiara Buat Keluarga (pp. 12-14). Mitra Pustaka.

Rahmaningsih, N. D., \& Martani, W. (2014). Dinamika Konsep Diri Pada Remaja Perempuan Pembaca. Teenlit. Jurnal Psikologi, 4(4), 186-190.

Shiddiqi, H. ash. (2008). Al-Qur'an dan Terjemahannya (p. 128). Toha Putra. 
Singgih, G. (2008). Psikologi Olahraga Prestasi (p. 27). PT BKK Gunung Mulia.

Slameto. (2010). Belajar dan Faktor-Faktor yang Mempengaruhinya (p. Hal. 2). PT Rineka Cipta.

Sudijono, A. (2009). Pengantar Statistik Pendidikan (p. 180). Raja Grafindo Persada.

Sukmadinata, N. S. (2005). Landasan psikologi proses pendidikan (p. h.3). Remaja Rosdakarya.

Suryabrata, S. (1998). Psikologi Pendidikan (p. 249). Rajawali Press.

Syah, M. (2011). Psikologi Belajar (p. 141). PT. Raja Grafindho Persada.

Triyanto, T. (2014). Pengantar Pendidikan (p. hal. 23-24). PT Bumi Aksara.

Tim Penyusun Kamus Pusat. (2001). Kamus Besar bahasa Indonesia (p. 512). Balai Pustaka.

Winkel, W. (1993). Psikologi Pendidikan (p. 161). Gramedia.

Zuhairini, D. (1992). Filsafat Pendidikan Islam (p. 173). Bumi Aksara. 